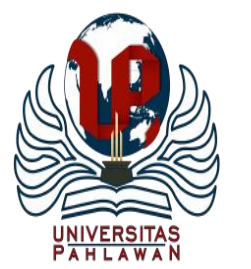

Edukatif : Jurnal Ilmu Pendidikan Volume 3 Nomor 2 Tahun 2021 Halm 529 - 538

EDUKATIF: JURNAL ILMU PENDIDIKAN

Research \& Learning in Education

https://edukatif.org/index.php/edukatif/index

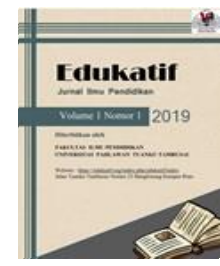

\title{
Minat dan Kebiasaan Baca Literatur Bahasa Inggris Mahasiswa Kesehatan
}

\author{
Jumaroh $^{1 凶}$, Aisyah $^{2}$ \\ Universitas Muhammadiyah Pekajangan Pekalongan, Indonesia ${ }^{1}$ \\ Universitas Muhammadiyah Pekajangan Pekalongan, Indonesia ${ }^{2}$ \\ E-mail : jumaroh@umpp.ac.id ${ }^{1}$, aisyah.khafifi@gmail.com ${ }^{2}$
}

\begin{abstract}
Abstrak
Perkembangan informasi dan teknologi dalam bidang kesehatan menuntut mahasiswa kesehatan untuk dapat menyesuaikan diri secara global dengan meningkatkan akses terhadap literatur berbahasa Inggris. Penelitian ini bertujuan untuk menggambarkan minat dan kebiasaan baca literatur berbahasa Inggris pada mahasiswa kesehatan. Metode yang digunakan dalam penelitian ini adalah deskriptif kuantitatif. Teknik pengambilan sampel yang digunakan adalah purposive sampling dan diperoleh 633 mahasiswa sebagai responden. Hasil penelitian menunjukkan minat dan kebiasaan baca literatur berbahasa Inggris pada mahasiswa masih rendah. Hal tersebut ditunjukkan dengan sebagian besar responden (72,2\%) menyatakan 'biasa saja' dan 'tidak suka' membaca literatur berbahasa Inggris. Waktu yang dihabiskan responden untuk membaca literatur Bahasa Inggris juga dikatakan dalam kategori sedikit, yaitu kurang dari satu jam perhari $(67,9 \%)$. Oleh karena itu, minat dan kebiasaan membaca literatur berbahasa Inggris mahasiswa perlu ditingkatkan salah satunya dengan mengintegrasikan kegiatan membaca literatur berbahasa Inggris dalam aktifitas perkuliahan. Selain itu pembentukkan program literasi sebagai kegiatan ektrakulikuler mahasiswa juga dapat menjadi upaya lain.
\end{abstract}

Kata Kunci: minat baca, literasi, mahasiswa kesehatan.

\begin{abstract}
The advancement of information and technology in health requires health science students to continuously adapt themselves globally and internationally by improving their access to various literature, especially those written in English. This study intended to give a description of students' reading interest and habit, especially toward English written literature. This study was carried out by a descriptive quantitative method. The respondents were 633 students who were selected by a purposive sampling technique. The research findings showed that students' interest and habit towards English-written literature were low. It can be derived from the majority (72.2\%) of the respondents who stated that they 'do not like' and 'dislike' reading Englishwritten literature. In addition, as much as $67.9 \%$ respondents spent less than an hour per day to read Englishwritten literature. Therefore, some integrative efforts to improve students' reading interest and to build students reading habit are needed, for instance, by integrating literacy program into students' learning activities of all courses.
\end{abstract}

Keywords: reading habit, reading interest, literacy, health science students.

Copyright (c) 2021 Jumaroh, Aisyah

$\triangle$ Corresponding author

Email : jumaroh@umpp.ac.id

DOI : https://doi.org/10.31004/edukatif.v3i2.336

ISSN 2656-8063 (Media Cetak)

ISSN 2656-8071 (Media Online)

Edukatif : Jurnal Ilmu Pendidikan Vol 3 No 2 Tahun 2021

p-ISSN 2656-8063 e-ISSN 2656-8071 


\section{PENDAHULUAN}

Terbentuknya budaya baca adalah salah satu katalis dalam perkembangan peradaban suatu bangsa. Masyarakat dengan budaya baca yang baik kerap diklaim sebagai pilar teguhnya demokrasi suatu negara (Oladele \& HawwauA, 2015; Jegbefume et al., 2017; Yusof, 2010). Beberapa literatur bahkan menyebutkan bahwa membaca merupakan perintah yang disampaikan nabi di beberapa agama (Black, 2010; Anyira \& Udem, 2020). Pentingnya menumbuhkan dan memelihara budaya membaca menjadi prioritas utama bagi mayoritas negara di dunia (Tavsanli \& Kaldirim, 2017), tidak terkecuali Indonesia. Demi menumbuhkembangkan budaya baca di masyarakat, pemerintah telah mencanangkan beberapa kebijakan dan strategi seperti Gerakan Literasi Sekolah (Wiedarti et al., 2016; Kemendikbud, 2015), program Gerakan Indonesia Membaca, dan Kampung Literasi yang diselenggarakan sejak 2015 (Kemendikbud, 2019).

Kontras dengan upaya-upaya yang digalakkan pemerintah, beberapa studi menunjukkan temuan yang cukup mengecewakan. Berdasarkan survei yang dilakukan oleh Central Connecticut State University (CCSU), Connecticut, Amerika Serikat, Indonesia berada pada urutan ke 60 dari 61 negara yang diteliti dalam hal literasi (CCSU, 2016). Indonesia hanya berada satu tingkat di atas Botswana, yang berada di posisi bungsu. Selain itu, Programme for International Student Assessment (PISA) yang diselenggarakan oleh Organization for Economic Co-operation and Development (OECD) menyimpulkan bahwa siswa Indonesia menunjukkan keterampilan membaca yang lebih rendah dari rata-rata siswa dari negara-negara anggota OECD lain (OECD, 2019). Rata-rata siswa Indonesia hanya meraih skor 371 dari skor total 600, sedangkan rata-rata seluruh negara peserta mencapai 487. Indonesia menempati urutan ke-4 terbawah dari 79 negara peserta. Di sisi lain, studi-studi yang dilakukan oleh peneliti Indonesia juga menunjukkan hal yang tidak jauh berbeda. Penelitian (Triatma, 2016) dengan subjek siswa sekolah dasar di Jogjakarta dan penelitian Siswati (2010) dengan mahasiswa sebagai subjek, menyimpulkan bahwa secara umum minat baca siswa Indonesia masih rendah.

Tingkat literasi yang baik seharusnya dimiliki oleh setiap individu sebagai bagian dari suatu bangsa. Hanya saja, profesi-profesi tertentu menuntut tingkat literasi dan kebiasaan baca yang lebih baik, salah satunya adalah tenaga kesehatan. Bagaimana tidak, tenaga kesehatan dituntut untuk selalu memperbarui dan menambah wawasan dalam rangka mengaktualisasi pengetahuan serta keterampilannya untuk dapat memberi pelayanan kesehatan terbaik. Upaya aktualisasi ini tentunya tidak dapat dilakukan tanpa membaca. Hampir segala bentuk penemuan, teori, maupun pendekatan termutakhir dipublikasikan dalam bentuk artikel-artikel pada jurnal-jurnal ilmiah, buku, maupun portal-portal berita. Maka, berhenti membaca sama dengan menutup akses tidak terbatas pada penemuan-penemuan serta pengetahuan-pengetahuan terkini. Bagi tenaga kesehatan, hal semacam ini tentu luas implikasinya.

Dalam proses pembelajaran di perguruan tinggi, mahasiswa kesehatan diharapkan telah mempunyai minat dan kebiasaan baca yang baik karena nantinya kebiasaan ini yang akan membantu mereka dalam proses aktualisasi wawasan. Selain minat baca secara umum, mahasiswa juga diharapkan memiliki minat yang tinggi pada literatur-literatur kesehatan dalam Bahasa Inggris. Minat dan kebiasaan baca literatur berbahasa Inggris sangat dibutuhkan mengingat perkembangan ilmu kesehatan dipublikasikan secara global dalam Bahasa Inggris. Di samping itu, kebiasaan ini akan turut meningkatkan keterampilan berbahasa Inggris yang akan sangat bermanfaat bagi tenaga kesehatan untuk dapat menguasai teknologi di bidang kesehatan dan berkiprah di dunia kesehatan internasional.

Dalam rangka menanamkan minat dan kebiasaan baca yang baik, pengajar Bahasa Inggris harus memahami gambaran minat baca mahasiswa terutama pada literatur berbahasa Inggris. Pemahaman tersebut dapat menjadi bekal dalam menentukan kebutuhan mahasiswa dan tujuan pembelajaran (needs analysis), serta mengeksplorasi berbagai metode pembelajaran guna meningkatkan learning outcome terutama pada mata kuliah Bahasa Inggris. Keterampilan dan minat baca yang baik akan literatur berbahasa Inggris ini diharapkan 
dapat menjadi bekal bagi para calon tenaga kesehatan untuk senantiasa belajar dan mengaktualisasi diri mereka dengan perkembangan pengetahuan terkini di bidang kesehatan.

Studi terdahulu yang meneliti minat dan kebiasaan membaca salah satunya dilakukan oleh OwusuAcheaw (2014). Studi ini meneliti tentang pengaruh kebiasaan membaca terhadap prestasi akademik mahasiswa Politeknik Koforidua, Ghana. Studi ini menunjukkan bahwa mayoritas responden meyakini kebiasaan membaca yang baik memberikan dampak positif pada prestasi akademik mereka. Data juga menunjukkan bahwa kebiasaan membaca mempunyai dampak langsung terhadap prestasi akademik mahasiswa.

Studi tentang kebiasaan membaca lainnya dilakukan oleh Soliman dan Neel (2009) di Medical College King Saud University, Arab Saudi. Studi ini mendeskripsikan kebiasaan baca mahasiswa yang juga calon tenaga kesehatan. Studi tersebut memperlihatkan bahwa kebiasaan baca mahasiswa tidak telalu baik, terlebih bahan bacaan mahasiswa-mahasiswa tersebut secara umum hanya terikat pada buku ajar yang digunakan dalam proses pembelajaran di perguruan tinggi.

Pada penelitian-penelitian tersebut, peneliti tidak membahas dan mengaitkan kebiasaan baca mahasiswa pada bahasa tertentu. Kemudian, pada penelitian yang dilakukan oleh Soliman dan Fouda, misalnya, sumber bacaan yang diteliti hanya berupa buku ajar saja. Padahal, pada era globalisasi seperti sekarang ini, selain kebiasaan dalam membaca, konten dan bahasa yang digunakan dalam bahan bacaan juga sama pentingnya. Menguasai bahasa internasional adalah kunci untuk mendapatkan berbagai informasi dari berbagai belahan dunia (Mustika \& Lestari, 2020). Selain itu, bahan bacaan juga tidak kalah pentingnya karena bahan bacaan berkaitan erat dengan minat baca dan kesan yang didapatkan pembaca saat membaca. Bacaan yang sesuai dengan minat pembaca dapat memunculkan perasaan menyenangkan saat dibaca dan dapat menumbuhkan kebiasaan baca. Oleh karena itu, pada penelitian ini, minat pada jenis bacaan serta bahasa yang digunakan dalam bacaan juga akan menjadi fokus penelitian.

\section{METODE PENELITIAN}

Penelitian yang dilakukan ini merupakan studi deskriptif kuantitatif yang meliputi minat serta kebiasaan membaca atau 'reading interest' dan 'reading habit' mahasiswa khususnya pada literatur bahasa Inggris, serta kendala-kendala yang dihadapi mahasiswa dalam membaca literatur bahasa Inggris. Populasi dari penelitian ini adalah mahasiswa kesehatan tingkat I sampai IV. Sampel dipilih dengan teknik purposive sampling dengan kriteria inklusi kesediaan mahasiswa untuk berpartisipasi dalam penelitian.

Segala data yang dibutuhkan dalam penelitian ini direkam dan dihimpun melalui kuesioner yang didistribusikan dan diisi oleh responden secara daring (online) serta bersifat sukarela. Metode tersebut dipilih untuk melindungi kerahasiaan identitas serta data yang diberikan oleh responden. Data yang diambil meliputi minat responden terhadap kegiatan membaca, rata-rata lama mereka membaca setiap harinya, media maupun jenis bacaan yang digunakan, kendala dalam membaca literatur berbahasa Inggris dan sebagainya. Data-data tersebut direkam dalam satu kuesioner yang terdiri dari beberapa butir pertanyaan close-ended dan openended. Butir-butir soal tersebut secara umum meliputi dua hal, yaitu minta baca mahasiswa dan kebiasaan baca mahasiswa pada literatur berbahasa Inggris. Proses pengambilan data dilakukan pada Januari 2021.

\section{HASIL DAN PEMBAHASAN}

Dari total 1244 mahasiswa tingkat I sampai IV, sejumlah 633 mahasiswa bersedia mengisi kuesioner yang diberikan. Karena penelitian hanya berfokus pada minat dan kebiasaan membaca mahasiswa, karakter maupun data pribadi dari masing-masing responden tidak akan dibahas kecuali jenjang pendidikan yang 
sedang ditempuh. Data tersebut diambil untuk memberi sedikit gambaran karena dimungkinkan terdapat perbedaan minat maupun kebiasaan membaca mahasiswa pada jenjang studi yang berbeda.

Tabel 1. Jenjang Pendidikan Responden (n=633)

\begin{tabular}{lcc}
\hline & Diploma Tiga & Sarjana \\
\hline Tingkat I & 39 & 149 \\
\hline Tingkat II & 66 & 146 \\
\hline Tingkat III & 42 & 100 \\
\hline Tingkat IV & - & 91 \\
\hline Total & $147(23,3 \%)$ & $486(76,7 \%)$ \\
\hline
\end{tabular}

Dapat dilihat di Tabel 1, jumlah responden dengan jenjang pendidikan diploma tiga lebih sedikit jika dibandingkan dengan jumlah responden jenjang sarjana. Namun komposisi tersebut tidak terlepas dari rasio populasi total mahasiswa diploma tiga berbanding mahasiswa sarjana sebesar 3:7 atau sekitar 29,9\% berbanding $70,1 \%$. Selanjutnya, secara kuantitatif minat atau preferensi baca mahasiswa disajikan pada Tabel 2 - 9. Kebiasaan membaca mahasiswa digambarkan di Tabel $10-13$. Tabel-tabel berikut akan menyajikan data berdasarkan pertanyaan-pertanyaan yang diajukan kepada responden melalui kuesioner.

Tabel 2. Apakah Anda suka membaca? $(n=633)$

\begin{tabular}{lccc}
\hline & Diploma Tiga & Sarjana & Total \\
\hline Ya & $86(58,5 \%)$ & $241(49,6 \%)$ & $327(51,7 \%)$ \\
\hline Biasa saja & $61(41,5 \%)$ & $238(49 \%)$ & $299(47,2 \%)$ \\
\hline Tidak & - & $7(1,4 \%)$ & $7(1,1 \%)$ \\
\hline
\end{tabular}

Tabel 3. Apakah Anda suka membaca literatur berbahasa Inggris? $(n=633)$

\begin{tabular}{lccc}
\hline & Diploma Tiga & Sarjana & Total \\
\hline Ya & $34(23,1 \%)$ & $142(29,2 \%)$ & $176(27,8 \%)$ \\
\hline Biasa saja & $94(64 \%)$ & $299(61,5 \%)$ & $393(62,1 \%)$ \\
\hline Tidak & $19(12,9 \%)$ & $45(9,3 \%)$ & $64(10,1 \%)$ \\
\hline
\end{tabular}

Tabel 2 dan 3 menyajikan distribusi minat baca pada mahasiswa kesehatan. Berdasarkan data tersebut dapat disimpulkan bahwa minat baca mahasiswa kesehatan jenjang diploma tiga lebih tinggi dari minat baca mahasiswa kesehatan jenjang sarjana dengan selisih sebesar 8,9\%. Hanya saja, baik mahasiswa diploma tiga maupun mahasiswa sarjana mempunyai minat yang rendah terhadap bacaan atau literatur berbahasa Inggris. Namun, mahasiswa keperawatan mempunyai minat yang sedikit lebih tinggi terhadap literatur berbahasa Ingris dibanding mahasiswa diploma tiga dengan selisih 6,1\%. Lebih singkat dapat dikatakan bahwa secara umum mahasiswa diploma tiga keperawatan mempunyai minat baca yang lebih tinggi dibanding mahasiswa sarjana, namun minat baca terhadap literatur berbahasa Inggris mahasiswa diploma tiga justru lebih rendah dari mahasiswa keperawatan.

Pertanyaan selanjutnya menanyakan motivasi yang mendorong mahasiswa untuk membaca literatur berbahasa Inggris. Pada pertanyaan tersebut, mahasiswa dipersilahkan untuk memilih lebih dari satu jawaban. Jawaban yang paling banyak diberikan mahasiswa adalah 'ingin meningkatkan keterampilan berbahasa Inggris' sebesar 47,4\%, 'ingin tahu' sebesar 41,2\%, 'tugas dari dosen' sebesar 31,6\%, dan karena 'suka' sebesar 6,2\%. Jawaban lain yang muncul antara lain ingin memahami film dengan Bahasa Inggris, ingin fasih berbahasa Inggris agar bisa bekerja di luar negeri, ingin mendapat banyak informasi kesehatan, dan lain sebagainya. Bentuk bahan bacaan yang paling sering diakses mahasiswa dapat dilihat pada Tabel 4. 
Tabel 4. Bentuk literatur yang paling sering Anda baca? (n=633)

\begin{tabular}{lc}
\hline Sumber bacaan & Jumlah Respon \\
\hline Cetak & $29(4,6 \%)$ \\
\hline Online/elektronik & $321(50,7 \%)$ \\
\hline Keduanya & $283(44,7 \%)$ \\
\hline
\end{tabular}

Tabel 5. Sumber literatur cetak apa saja yang sering Anda gunakan? $(\mathrm{n}=633)$

\begin{tabular}{lc}
\hline Jenis Literatur Cetak & Jumlah Respon \\
\hline Novel/karangan fiksi lain & $438(69,2 \%)$ \\
\hline Buku ajar & $195(30,8 \%)$ \\
\hline Majalah & $65(10,3 \%)$ \\
\hline Ensiklopedia & $59(9,3 \%)$ \\
\hline Surat kabar & $40(6,3 \%)$ \\
\hline
\end{tabular}

Tabel 6. Sumber literatur online/elektronik apa saja yang sering Anda gunakan? (n=633)

\begin{tabular}{lc}
\hline Jenis Literatur Online/Elektronik & Jumlah Respon \\
\hline Media sosial & $402(63,5 \%)$ \\
\hline Novel, komik, dan sejenisnya & $305(48,2 \%)$ \\
\hline Portal berita mainstream (kompas, tempo, dsb.) & $144(22,7 \%)$ \\
\hline Portal berita hiburan & $82(13 \%)$ \\
\hline
\end{tabular}

Tabel 4, 5, dan 6 mendeskripsikan minat baca mahasiswa secara umum, tanpa mendiferensisasi bahasa yang digunakan dalam sumber bacaan. Dari Tabel 4, sangat jelas terlihat bahwa mahasiswa cenderung lebih menyukai sumber bacaan online daripada bacaan cetak. Sebanyak 95,4\% mahasiswa mengaku sering menggunakan media online. Hanya 4,6\% mahasiswa saja yang mengaku lebih sering menggunakan media cetak saja tanpa media online. Data ini sejalan dengan studi yang dilakukan (Satriani, 2018) yang menemukan adanya pergeseran budaya baca mahasiswa dari membaca tradisional dengan bacaan cetak, menjadi membaca dengan memanfaatkan teknologi berupa sumber-sumber bacaan elektronik/online. Menurut (Satriani, 2018), pergeseran tersebut salah satunya disebabkan oleh pemanfaatan teknologi internet yang menjadi sangat populer di dua dekade terakhir. Sayangnya, seperti yang dapat dilihat pada Tabel 6, jenis bacaan online/elektronik yang paling banyak diakses mahasiswa adalah media sosial.

Media sosial memungkinkan penggunanya untuk berkomunikasi dan berbagi informasi dengan sangat mudah tanpa kendala batasan tempat, biaya, dan waktu (Harahap et al., 2021). Di sisi lain, penggunaan media sosial juga mempunyai berbagai potensi negatif seperti terganggunya kegiatan belajar, terfasilitasinya tindak kejahatan, terganggunya komunikasi dalam keluarga, terkikisnya nilai-nilai budaya, adat istiadat, norma, dan etika yang berlaku di masyarakat (Harahap et al., 2021), serta munculnya beberapa tanda gangguan kejiwaan seperti depresi, self-esteem, kecemasan, ketidakpuasan terhadap bentuk tubuh, dan lain sebagainya (Sharma et al., 2020; Deepa \& Priya, 2020). Selain itu, penggunaan media sosial juga berpotensi menimbulkan konflik sosial karena pengguna dapat dengan mudah menyebarluaskan berita tanpa harus memastikan keabsahan dari berita tersebut (Harahap et al., 2021). Oleh karena itu, kebiasaan membaca literatur atau informasi yang disebarluaskan melalui sosial media dapat menimbulkan berbagai efek negatif bagi masyarakat, termasuk mahasiswa. Sehingga, peran pendidik dan orang tua dalam mengarahkan generasi muda untuk memilih sumber bacaan yang baik sangatlah krusial.

Kemudian, walaupun hanya 55,3\% mahasiswa saja yang mengaku masih sering membaca dari literatur cetak, namun sebagian besar bacaan yang diakses mahasiswa adalah literatur yang dibaca sebagai bahan hiburan (pleasure reading) seperti karangan fiksi, majalah, ensiklopedia, dan surat kabar. Kegiatan pleasure 
reading tersebut juga banyak dilakukan mahasiswa dengan membaca sumber-sumber online berupa karangan fiksi dan portal berita. Manurut Al Yaaqubi \& Al Mahrooqi (2013), pleasure reading dapat memberi banyak manfaat pada pembaca di antaranya meningkatkan keterampilan berbahasa, melatih kecerdasan sosial, dan meningkatkan rasa percaya diri. Studi tersebut juga mengungkapkan bahwa karya sastra atau fiksi adalah jenis literatur yang paling banyak dibaca dalam pleasure reading. Dalam studinya, Howard (2011) mengemukakan hal yang sejalan bahwa pleasure reading dapat meningkatkan prestasi akademik, menumbuhkan kesadaran sosial dan empati, dan yang utama adalah meningkatkan literacy skills. Tidak hanya dalam membaca literatur berbahasa Indonesia, sebagian mahasiswa juga memiliki kebiasaan pleasure reading dengan bacaan berbahasa Inggris. Data yang lebih rinci mengenai hal ini dapat dilihat pada Tabel $7-9$.

Tabel 7. Bentuk literatur berbahasa Inggris yang paling sering Anda baca? ( $n=633)$

\begin{tabular}{lc}
\hline & Jumlah Respon \\
\hline Cetak & $48(7,6 \%)$ \\
\hline Online/elektronik & $391(61,8 \%)$ \\
\hline Keduanya & $188(29,7 \%)$ \\
\hline Tidak menjawab & $6(0,9 \%)$ \\
\hline
\end{tabular}

Tabel 8. Sumber literatur cetak berbahasa Inggris apa saja yang sering Anda gunakan? $(\mathrm{n}=633)$

\begin{tabular}{lc}
\hline Jenis Literatur Cetak Bahasa Inggris & Jumlah Respon \\
\hline Novel, komik, dan karangan fiksi lain & $249(39,3 \%)$ \\
\hline Buku Ajar & $235(37,1 \%)$ \\
\hline Artikel ilmiah & $208(32,9 \%)$ \\
\hline Ensiklopedia & $52(8,2 \%)$ \\
\hline Majalah & $46(7,3 \%)$ \\
\hline Surat kabar & $12(1,9 \%)$ \\
\hline
\end{tabular}

Tabel 9. Sumber literatur online/elektronik berbahasa Inggris apa saja yang sering Anda gunakan? $(n=633)$

\begin{tabular}{lc}
\hline Jenis Literatur Online/Elektronik Bahasa Inggris & Jumlah Respon \\
\hline Novel, komik, dan karangan fiksi lain & $314(49,6 \%)$ \\
\hline Blog & $199(31,4 \%)$ \\
\hline Portal berita & $147(23,2 \%)$ \\
\hline Ensiklopedia & $91(14,4 \%)$ \\
\hline
\end{tabular}

Bentuk sumber bacaan berbahasa Inggris yang dibaca mahasiswa tidak jauh berbeda dari bentuk sumber bacaan yang dibaca mahasiswa secara umum. Jumlah mahasiswa yang lebih sering mengakses literatur berbahasa Inggris dalam bentuk cetak saja berjumlah 48 orang atau lebih tinggi 3\% dibanding sumber bacaan umum. Uniknya, mahasiswa yang lebih suka mengakses bacaan berbahasa Inggris dalam bentuk online saja juga meningkat sebanyak 11,1\% dibandingkan dengan mahasiswa penyuka bacaan umum online. Jadi dalam membaca literatur berbahasa Inggris, mahasiswa lebih cenderung mempunyai preferensi terhadap bentuk tertentu saja dibanding keduanya sekaligus. Hal ini dapat dilihat dari penyuka kedua bentuk sumber bacaan (cetak dan online) yang menurun dari 44,7\% di bacaan umum, menjadi 29,7\% pada bacaan berbahasa Inggris.

Jenis bacaan berbahasa Inggris yang diakses mahasiswa tidak jauh berbeda dengan jenis-jenis bacaan mereka secara umum. Mahasiswa yang sering membaca literatur online berbahasa Inggris sebanyak 91,5\%, sementara yang membaca sumber cetak berbahasa Inggris sebanyak 37,3\%. Sumber bacaan berbahasa Inggris untuk pleasure reading juga banyak diakses mahasiswa dengan jenis terbanyak karangan fiksi. Jadi 
mahasiswa tidak hanya membaca literatur berbahasa Inggris untuk memenuhi tugas perkuliahan saja. Beberapa perbedaan yang muncul di antaranya adalah mahasiswa juga tidak mengakses media sosial untuk mendapatkan literatur berbahasa Inggris. Selain itu, sumber bacaan dengan jenis artikel ilmiah justru muncul pada sumber bacaan cetak berbahasa Inggris. Normalnya, artikel ilmiah, terutama dengan bahasa asing, lebih mudah ditemukan dalam bentuk online. Mahasiswa membaca artikel ilmiah berbahasa Inggris bukanlah merupakan hal yang aneh. Banyak dosen-dosen yang meminta mahasiswa mencari referensi perkuliahan melalui artikel ilmiah. Hal ini menjadi sedikit berbeda justru karena mahasiswa yang membaca artikel ilmiah berbahasa Inggris dalam bentuk online jumlahnya tidak banyak, hanya tujuh mahasiswa. Namun, mahasiswa yang membaca arikel ilmiah berbahasa Inggris justru berjumlah 208 orang. Terdapat beberapa kemungkinan yang melatar belakangi temuan ini. Pertama, mencari artikel ilmiah berbahasa Inggris bukanlah merupakan hal yang mudah bag sebagian besar mahasiswa. Kemungkinan berikutnya, mahasiswa hanya membaca artikel ilmiah berbahasa Inggris yang dibagikan oleh dosen dalam rangka pengerjaan tugas. Untuk itu, dosen pengajar disarankan untuk mengajari, mencontohkan, dan membiasakan mahasiswa untuk mengakses artikel ilmiah berbahasa Inggris.

Selain bentuk dan jenis bacaan, pertanyaan yang diajukan melalui kuesioner juga menyangkut manfaat yang dirasakan mahasiswa dari kebiasaan membaca literatur berbahasa Inggris. Karena pertanyaan bersifat open-ended, mahasiswa bebas menyatakan respon mereka. Jawaban yang paling banyak diberikan mahasiswa antara lain: menambah perbendaharaan kata Bahasa Inggris (474 atau 74,9\% mahasiswa), meningkatkan keterampilan berbahasa Inggris (303 atau 47,9\% mahasiswa), menambah pengetahuan (222 atau 35,1\% mahasiswa), dan mengasah logika (139 atau 22\% mahasiswa). Tabel-tabel berikutnya akan menyajikan data yang berkaitan dengan kebiasaan baca mahasiswa baik secara umum maupun pada literatur berbahasa Inggris.

Tabel 10. Berapa lama waktu yang Anda gunakan untuk membaca setiap harinya? (n=633)

\begin{tabular}{lccc}
\hline & Diploma Tiga & Sarjana & Total \\
\hline Tidak ada & - & $9(1,9 \%)$ & $9(1,4 \%)$ \\
\hline Kurang dari 1 jam & $72(49 \%)$ & $223(45,9 \%)$ & $295(46,6 \%)$ \\
\hline 1 -2 jam & $63(42,9 \%)$ & $212(43,6 \%)$ & $275(43,4 \%)$ \\
\hline Lebih dari 2 jam & $12(8,2 \%)$ & $42(8,6 \%)$ & $54(8,5 \%)$ \\
\hline
\end{tabular}

Tabel 11. Barapa lama waktu yang Anda gunakan untuk membaca literatur berbahasa Inggris setiap harinya? $(n=633)$

\begin{tabular}{lccc}
\hline & Diploma Tiga & Sarjana & Total \\
\hline Tidak pernah & $15(10,2)$ & $47(9,7 \%)$ & $62(9,8 \%)$ \\
\hline Kurang dari 1 jam & $98(66,7 \%)$ & $332(68,3 \%)$ & $430(67,9 \%)$ \\
\hline 1 -2 jam & $30(20,4 \%)$ & $95(19,5 \%)$ & $125(19,7 \%)$ \\
\hline Lebih dari 2 jam & $4(2,7 \%)$ & $12(2,5 \%)$ & $16(2,5 \%)$ \\
\hline
\end{tabular}

Tabel 10 menunjukkan bahwa sebagian besar mahasiswa, baik pada program diploma (91,8\%) maupun sarjana (91,4\%), menghabiskan waktu paling lama 2 jam per hari untuk membaca. Hanya 8,5\% responden saja yang membaca lebih dari 2 jam per hari. Dari durasi tersebut, sebagian besar $(77,7 \%)$ mahasiswa menggunakan waktu kurang dari satu jam untuk membaca literatur berbahasa Inggris. Dari data tersebut dapat dikatakan bahwa kebiasaan baca belum terbentuk di kalangan mahasiswa baik pada jenjang diploma tiga maupun sarjana. Hanya sedikit sekali mahasiswa yang membaca lebih dari 2 jam per hari, baik untuk bacaan berbahasa Inggris maupun bacaan lainnya. Hal ini senada dengan studi yang dilakukan (Soliman \& Neel, 2009) yang mengungkapkan kebiasaan baca mahasiswa kesehatan yang tidak telalu baik dan hanya terbatas pada buku ajar yang digunakan di perkuliahan. 
Untuk memberi sedikit tambahan gambaran tentang kegiatan atau hobi yang lebih disukai dan kemungkinan juga dapat menghambat terbentuknya minat dan kebiasaan baca mahasiswa, Tabel 12 menyajikan daftar kegiatan yang lebih disukai responden dibanding membaca, dan Table 13 menyajikan durasi waktu yang digunakan mahasiswa untuk melakukan kegiatan atau hobi tersebut.

Tabel 12. Kegiatan apa yang lebih Anda sukai dibanding membaca? $(n=633)$

\begin{tabular}{lc}
\hline Jenis Kegiatan & Jumlah Respon \\
\hline Menonton film/televisi & $168(26,5 \%)$ \\
\hline Olah raga & $66(10,4 \%)$ \\
\hline Bermain gawai & $65(10,3 \%)$ \\
\hline Mendengarkan musik & $65(10,3 \%)$ \\
\hline Menulis & $36(5,7 \%)$ \\
\hline Memasak & $27(4,3 \%)$ \\
\hline Menggambar & $11(1,7 \%)$ \\
\hline
\end{tabular}

Tabel 13. Berapa lama waktu yang Anda gunakan untuk melakukan kegiatan tersebut setiap harinya? $(\mathbf{n}=633)$

\begin{tabular}{lcc}
\hline Durasi Kegiatan / Hari & Jumlah Respon & Prosentase \\
\hline Kurang dari 1 jam & 99 & $15,6 \%$ \\
\hline 1-2 jam & 288 & $45,5 \%$ \\
\hline 3-4 jam & 139 & $22 \%$ \\
\hline Lebih dari 4 jam & 90 & $14,2 \%$ \\
\hline
\end{tabular}

Jawaban mahasiswa pada pertanyaan 12 sangatlah beragam. Kegiatan yang disebutkan di atas hanyalah kegiatan-kegiatan yang paling banyak disebut mahasiswa. Berdasarkan data yang disajikan pada Tabel 12, kegiatan yang paling banyak disukai mahasiswa melebihi membaca adalah menonton film, drama, maupun acara di televisi. Mahasiswa bahkan meluangkan lebih banyak waktu mereka untuk melakukan kegiatankegiatan tersebut. Sebanyak $84,4 \%$ mahasiswa menghabiskan lebih dari satu jam perhari, dan $14,5 \%$ di antaranya bahkan menghabiskan lebih dari 4 jam sehari untuk melakukan hobi selain membaca. Hal ini sejalan dengan hasil penelitian yang dilakukan oleh (Siswati, 2010) yang menyatakan bahwa salah satu alasan bagi mahasiswa tidak bisa mengembangkan hobi membaca mereka adalah kebiasaan mereka menonton televisi selama rata-rata dua jam sehari. Porsi waktu yang cukup banyak ini tentu saja dapat mengganggu mahasiswa dalam membentuk budaya baca karena waktu senggang yang dimiliki mahasiswa kesehatan dapat dikatakan sangat terbatas.

Selain kegiatan-kegiatan di atas, beberapa hal yang menurut mahasiswa menghambat minat mereka untuk membaca literatur berbahasa Inggris adalah kesukaran mereka dalam memahami arti dari setiap kata pada bacaan yang ingin mereka baca. Hambatan tersebut dirasakan oleh 541 (85,5\%) responden. Mahasiswa berkeyakinan bahwa mereka harus memahami setiap kata yang mereka temukan dalam setiap bacaan yang mereka baca. Dalam mempelajari bahasa asing, saat fokus utama dari setiap kegiatan adalah untuk menerjemahkan setiap satuan linguistiknya, maka proses untuk memahami bahasa tersebut justru akan terhambat.

Selain makna, yang menjadi hambatan terbesar mahasiswa dalam membaca literatur berbahasa Inggris adalah sulitnya akses untuk mendapatkan sumber bacaan yang sesuai dengan kebutuhan atau keinginan responden. Hambatan tersebut dialami oleh $140(22,1 \%)$ responden. Data ini cukup beralasan mengingat mahasiswa justru lebih sering membaca artikel ilmiah berbahasa Inggris dalam bentuk cetak dibanding online walaupun sebenarnya sebagian besar artikel ilmiah berbahasa Inggris justru tersedia online. Pada dasarnya, 
materi maupun bacaan berbahasa Inggris adalah materi yang paling melimpah ruah di internet. Apabila mahasiswa merasa kesusahan untuk menemukan sumber bacaan, hal tersebut adalah pertanda bahwa mahasiswa belum terbiasa mencari informasi di internet dengan Bahasa Inggris yang mereka anggap asing. Seiring dengan berjalannya waktu, apabila mahasiswa tidak berhenti berusaha dan mencoba membuat Bahasa Inggris lebih familiar baginya, maka pemahaman dan budaya baca akan terbentuk dengan sendirinya.

\section{KESIMPULAN}

Dari hasil dan pembahasan dapat disimpulkan bahwa responden secara umum belum mempunyai kebiasaan baca yang baik, terutama dalam membaca literatur berbahasa Inggris. Dari 633 mahasiswa yang menjadi responden, sejumlah $51,7 \%$ responden suka membaca. Sayangnya, hanya $27,8 \%$ saja yang suka membaca literatur berbahasa Inggris. Di samping itu, sebagian besar responden membaca kurang dari 2 jam setiap harinya. Dari durasi waktu tersebut, waktu yang mereka gunakan untuk membaca literatur berbahasa Inggris masih di bawah satu jam per hari. Kemudian, baik bacaan berbahasa Indonesia maupun Inggris, sebagian besar responden lebih memilih mengakses data secara online daripada dalam bentuk cetak. Kegiatan lain yang umumnya dilakukan mahasiswa dengan durasi lama dan menghambat mereka mengembangkan kebiasaan bacanya antara lain menonton televisi/film, olahraga, bermain gawai, dan lain-lain. Sementara itu hambatan lain yang juga dihadapi siswa untuk membaca literatur berbahasa Inggris adalah makna kata yang tidak diketahui, serta sulitnya akses untuk mencari sumber bacaan berbahasa Inggris.

Berdasarkan temuan tersebut, minat dan kebiasaan membaca literatur berbahasa Inggris mahasiswa perlu ditingkatkan salah satunya dengan mengintegrasikan kegiatan membaca literatur berbahasa Inggris dalam aktifitas perkuliahan. Dosen diharapkan mampu membimbing mahasiswa untuk memilih bacaan yang baik, serta menunjukkan cara untuk mengakses sumber-sumber bacaan tersebut. Selain itu, pembentukkan program literasi sebagai kegiatan ektrakulikuler mahasiswa juga dapat menjadi upaya lain. Program ini diharapkan mampu membuat mahasiswa menikmati kegiatan membaca, terutama literatur berbahasa Inggris.

\section{UCAPAN TERIMA KASIH}

Puji syukur kami haturkan pada Tuhan yang Maha Esa atas terlaksananya penelitian ini. Terima kasih kami ucapkan pula kepada LPPM Universitas Muhammadiyah Pekajangan Pekalongan atas segala dukungan yang diberikan sehingga penelitian ini dapat terlaksana, terlaporkan, dan terpublikasi dengan baik.

\section{DAFTAR PUSTAKA}

Al Yaaqubi, A., \& Al Mahrooqi, R. (2013). How does Reading Literature for Pleasure Affect EFL Learners? Asian EFL Journal. Professional Teaching Articles, 72(November), 20-46. http://www.asian-efljournal.com

Anyira, I. E., \& Udem, O. K. (2020). Effect of Social Media Addiction on Reading Culture: A Study of Nigerian Students. Library Philosophy and Practice, 2020(August), 1-17.

Black, J. (2010). The Secret History of the World. Quercus Publishing.

CCSU. (2016). World's most literate nations ranked. https://webcapp.ccsu.edu

Deepa, M., \& Priya, K. (2020). Impact of Social Media on Mental Health of Students. International Journal of Scientific \& Technology Research, 9(03).

Harahap, M., Ahmad, R., Padang, U. N., Barat, S., \& Ahmad, R. (2021). EDUKATIF : JURNAL ILMU PENDIDIKAN Penggunaan Social Media dan Perubahan Sosial Budaya Masyarakat. 3(1), 135-143. 
Howard, V. (2011). The importance of pleasure reading in the lives of young teens: Self-identification, selfconstruction and self-awareness. Journal of Librarianship and Information Science, 43(1), 46-55. https://doi.org/10.1177/0961000610390992

Jegbefume, C. M., Yaji, G. S., \& Dala, H. S. (2017). Improved Reading Culture : A Panacea for Sustainable National Development. International Journal of Applied Technologies in Library and Information Management, 3(April), 66-73. http://www.jatlim.org/volumes/volume3/vol3-1/Chukwudum.pdf

Kemendikbud. (2015). Mendikbud luncurkan gerakan literasi sekolah. https://www.kemdikbud.go.id/main/blog/2015/08/mendikbud-luncurkan-gerakan-literasi-sekolah-45144514-4514

Kemendikbud. (2019). Gerakan Indonesia Membaca Upaya Menumbuhkan Budaya Baca untuk Semua. Jendela Pendidikan Dan Kebudayaan. https://jendela.kemdikbud.go.id/v2/fokus/detail/gerakanindonesia-membaca-upaya-menumbuhkan-budaya-baca-untuk-semua

Mustika, N., \& Lestari, R. (2020). Metode Bermain Peran Dalam Meningkatkan Kemampuan Berbicara Bahasa Inggris Mahasiswa Stikes Perintis Padang. 2(2), 202-209.

OECD. (2019). Programme for international student assessment (PISA) results from PISA 2018. https://www.oecd-ilibrary.org/education/pisa-2018-results-volume-iii_bd69f805-

en\%0Ahttps://www.oecd-ilibrary.org//sites/bd69f805-

en/index.html?itemId=/content/component/bd69f805-en\#fig86

Oladele, M. J., \& HawwauA, M. (2015). The State of Reading in Faculty Libraries: A Socio-Economic Analysis. IOSR Journal Of Humanities And Social Science Ver. II, 20(6), 51-58. https://doi.org/10.9790/0837-20625158

Owusu-Acheaw, M. (2014). Reading Habits Among Students and its Effect on Academic Performance: A Study of Students of Koforidua Polytechnic. Library Philosophy and Practice (e-Journal), 1130 https://doi.org/10.1109/VLSI-SoC.2013.6673255

Satriani, E. (2018). Sumber Bacaan Online Dalam Membangun Reading Habit Mahasiswa Universitas Islam Riau. Lectura : Jurnal Pendidikan, 9(2), 168-178. https://doi.org/10.31849/lectura.v9i2.1607

Sharma, M. K., John, N., \& Sahu, M. (2020). Influence of social media on mental health: a systematic review. Current Opinion in Psychiatry, 33. https://doi.org/10.1097/YCO.0000000000000631

Siswati. (2010). Minat Membaca Pada Mahasiswa. Jurnal Psikologi Undip, 8(2), 124-134. https://ejournal.undip.ac.id

Soliman, M. M., \& Neel, K. F. (2009). The reading habits of medical students at Medical College King Saud University. Journal of Taibah University Medical Sciences, 4(2), 115-122. https://doi.org/10.1016/S1658-3612(09)70100-3

Tavsanli, O. F., \& Kaldirim, A. (2017). Examining the Reading Habits, Interests, Tendencies of the Students Studying at the Faculty of Education and Analyzing the Underlying Reason Behind Their Preferences. European Journal of Educational Research, 6(2), 145-156. https://doi.org/10.12973/eu-jer.6.2.145

Triatma, I. N. (2016). Minat baca pada siswa kelas Vi Sekolah Dasar Negeri Delegan 2 Prambanan Sleman Yogyakarta. E-Jurnal Prodi Teknologi Pendidikan, 5(6), 166-178. http://journal.student.uny.ac.id/ojs/index.php/fiptp/article/view/3098/0

Wiedarti, P., Laksono, K., Retnaningsih, P., Dewayani, S., Muldian, W., Sufyadi, S., Roosaria, R., Faizah, D. U., Sulastri, Rahmawan, N., Rahayu, E. S., Yusuf, R. A., \& Antoro, B. (2016). Desain Induk Gerakan Literasi Sekolah. Direktorat Jenderal Pendidikan Dasar dan Menengah Kementrian Pendidikan dan Kebudayaan.

Yusof, N. M. (2010). Influence of family factors on reading habits and interest among level 2 pupils in national primary schools in Malaysia. Procedia - Social and Behavioral Sciences, 5, 1160-1165. https://www.sciencedirect.com/science/article/pii/S1877042810016277 